\title{
Nomenclature survey of the genus Amaranthus (Amaranthaceae). 6. Names linked to the Australian flora
}

\author{
Duilio lamonico (iD) A,C and Jo Palmer ${ }^{\mathrm{B}}$ \\ A Laboratory of Phytogeography and Applied Geobotany, Department PDTA, Section Environment and Landscape, \\ University of Rome Sapienza, Via Flaminia 72, I-00196 Rome, Italy. \\ ${ }^{B}$ Australian National Herbarium, Centre for Australian National Biodiversity Research, CSIRO National \\ Collections and Marine Infrastructure (NCMI), GPO Box 1700, Canberra, ACT 2601, Australia. \\ ${ }^{\mathrm{C}}$ Corresponding author. Email: d.iamonico@yahoo.it
}

\begin{abstract}
In this paper, nomenclatural issues concerning nine Amaranthus taxa in the Australian flora are clarified. Lectotypes are designated for names of three currently accepted species (A. interruptus R.Br., A. rhombeus R.Br. and A. undulatus $\mathrm{R}$.Br.) and two names now being considered to be taxonomic synonyms (A. lineatus $\mathrm{R}$. Br. and $A$. macrocarpus var. pallidus Benth.). The earlier 'holotype' citations for the taxonomic synonym $A$. incurvatus Timeroy ex Gren. \& Godr. and the currently accepted species $A$. quitensis Kunth are here considered effective lectotypifications. The holotype material for the nomenclatural synonym A. mitchellii var. grandiflorus J.M.Black is clarified. A neotype is designated for A. pallidiflorus var. viridiflorus Thell. (now considered to be a taxonomic synonym).
\end{abstract}

Additional keywords: Australia, holotype, invalid name, lectotypification, neotype, syntypes.

Received 6 December 2018, accepted 9 August 2019, published online 5 February 2020

\section{Introduction}

The genus Amaranthus L. includes $\sim 70-75$ mostly annual monoecious and dioecious species with almost worldwide distribution (Sauer 1950, 1955, 1967; Robertson 1981; Mosyakin and Robertson 1996, 2003; Bayón 2015; Waselkov et al.2018, and references therein). Approximately 55 species are native to the Americas, with the remainder being native to other continents, with the exception of Antarctica (Costea et al. 2001; Hernández-Ledesma et al. 2015; Iamonico 2016). Many species of the genus are important agricultural or environmental weeds; several taxa are used as ornamentals or pseudocereals (Sauer 1950, 1967; Bayón 2015). Cultivated taxa can escape and become naturalised, sometimes causing economic impacts to agriculture and reduction in productivity and crop quality (Iamonico 2010; Iamonico and El Mokni 2018). The genus is taxonomically complex owing to its high phenotypic variability and hybridisation. These factors have caused nomenclatural confusion and misapplication of the available names (see comments in e.g. Mosyakin and Robertson 1996, 2003; Costea et al. 2001; Bayón 2015; Iamonico 2016).

Palmer (2009) provided a conspectus of the genus Amaranthus in Australia, but clarification of the typification of some names used in an Australian context is still required. In the current paper, we designate a neotype for one varietal name, lectotypes for four species names and one varietal name, correct an earlier citation of the 'holotype' to lectotype for two species names, and clarify the holotype material for one varietal name.

\section{Materials and methods}

Original material for the names of interest and other pertinent specimens are located in the herbaria AD, BM, K, MEL, MPU, NSW, P and Z. The names typified are listed alphabetically, with currently accepted names being indicated in notes if relevant. The Article (Art.) numbers cited throughout the text refer to the current (Shenzhen) edition of the International Code of Nomenclature for Algae, Fungi, and Plants (hereafter, abbreviated as ICN; Turland et al. 2018).

\section{Results and discussion}

As circumscribed in the current paper, the genus Amaranthus is represented in Australia by 26 species, with a single subspecies being recognised within $A$. graecizans L., and two varieties under A. macrocarpus Benth. (Palmer 2009). Of these, 11 species are indigenous, 14 naturalised, and one is an occasional garden escape. According to Palmer (2009), of the 27 accepted taxon names then applied to the Australian plants, 11 names had a holotype, 14 had been previously lectotypified, one name had a previously designated neotype, and, for one name (A. muricatus (Moq.) Hieron.), no type indication was given. Amaranthus muricatus was subsequently lectotypified by Iamonico (2016). Some of the 11 names reported by Palmer (2009) as having a holotype need further clarification, i.e. A. incurvatus Timeroy ex Gren. \& Godr., A. interruptus R.Br., A. lineatus R.Br., A. macrocarpus var. pallidus Benth., A. mitchellii var. 
Table 1. List of the newly typified or clarified Amaranthus names linked to the Australian flora

Accepted names are in bold

\begin{tabular}{|c|c|}
\hline Name & Type \\
\hline $\begin{array}{l}\text { Amaranthus incurvatus Timeroy ex Gren. \& Godr. } \\
\quad(=\text { A. hybridus L.) }\end{array}$ & Lecto, P 00502852! \\
\hline Amaranthus interruptus R.Br. & $\begin{array}{l}\text { Lecto, BM } 000847081 ! \\
\text { Isolecto, K } 000356720 !\end{array}$ \\
\hline Amaranthus lineatus $\mathrm{R} . \mathrm{Br}$. & $\begin{array}{l}\text { Lecto, BM } 000884578 ! \\
\text { Isolecto, K } 000356721 !\end{array}$ \\
\hline $\begin{array}{l}\text { Amaranthus macrocarpus var. pallidus Benth } \\
\quad \text { (= A. macrocarpus Benth.) }\end{array}$ & $\begin{array}{l}\text { Lecto, MEL 59713! } \\
\text { Isolecto, K 000357414! }\end{array}$ \\
\hline $\begin{array}{l}\text { Amaranthus mitchellii var. grandiflorus J.M.Black } \\
\quad(\equiv \text { A. grandiflorus (J.M.Black) J.M.Black) }\end{array}$ & Holo, AD 99436234! \\
\hline $\begin{array}{l}\text { Amaranthus pallidiflorus var. viridiflorus Thell. } \\
\qquad(\equiv \text { A. clementii Domin) }\end{array}$ & Neo, K $000357389 !$ \\
\hline Amaranthus quitensis Kunth & Lecto, P $00136030 !$ \\
\hline Amaranthus rhombeus $\mathrm{R} . \mathrm{Br}$. & $\begin{array}{l}\text { Lecto, BM 000522509! } \\
\text { Isolecto, K } 000356722 !\end{array}$ \\
\hline Amaranthus undulatus R.Br. & $\begin{array}{l}\text { Lecto, BM } 000522508 ! \\
\text { Isolecto, K } 000357415 !\end{array}$ \\
\hline
\end{tabular}

grandiflorus J.M.Black, A. quitensis Kunth, A. rhombeus R.Br. and A. undulatus R.Br. Furthermore, one additional name, A. pallidiflorus var. viridiflorus Thell., regarded as a taxonomic synonym by Palmer (2009), requires typification. These typifications are summarised in Table 1.

1. Amaranthus incurvatus Timeroy ex Gren. \& Godr., Fl. France Prosp. 8 (1846)

Type citation: 'Tigneu, village près Lyon'. Type: [France], Lyon, 1845?, Timeroy s.n. (lecto: P 00502852!, fide C.C.Townsend in R.M.Polhill (ed.), Fl. Trop. E. Africa 25 (1985) [image available at https://science.mnhn.fr/institution/mnhn/collection/p/item/ p00502852, accessed 1 November 2018]).

Grenier and Godron (1846) provided a detailed description of Amaranthus incurvatus and a comparison with $A$. retroflexus L. Townsend (1985, p. 25) gave the type citation as 'France, Lyon, 1845 Timeroy (P, holo.!)'. The specimen cited by Townsend is P 00502852. It bears two handwritten labels from M. A. Timeroy on the bottom left-hand side of the sheet. The first of these reads 'Amaranthus an species nova? Lyon | Timeroy $\mid 1845^{\prime}$, indicating Timeroy's original belief that the material possibly represented a new species. The second label reads "Amaranthus inflexus nob. | An A. patulus Guss.? | non A. chlorostachys certa $\mid$ Timeroy $\mid 1848$ ', indicating Timeroy's uncertainty as to whether the material represented Amaranthus patulus Bertol. or a new taxon. There is no evidence that Timeroy's manuscript name 'Amaranthus inflexus' was ever published. A third label, written by Townsend and dated 4 September 1973, on the centre left-hand side of the sheet, indicates Townsend's opinion that the specimen was 'Probably the type of A. incurvatus Tim. ex G. \& G. ...'

Although the locality matches the protologue, and the date of the first label precedes that of the original publication, we cannot be sure that Grenier and Godron (1846) used only this specimen in preparing the account of their new taxon. However, the addition of Townsend's label to P 00502852 and his citation of a specimen from Lyon held at $\mathrm{P}$ as the 'holo.' for A. incurvatus are here regarded as an effective lectotypification by Townsend (1985). Because Townsend's citation meets the relevant requirements of ICN Art. 7.11, his use of the term 'holo.' is correctable to 'lectotype' under ICN Art. 9.10.

According to current taxonomic concepts (e.g. Mosyakin and Robertson 2003; Iamonico 2015), Amaranthus incurvatus is regarded as a heterotypic synonym of $A$. hybridus $\mathrm{L}$.

\section{Amaranthus interruptus R.Br., Prodr. 414 (1810)}

Type citation: '(T.) v. v.'. Type: 'North Coast', R.Brown Iter Australiense 3048 (lecto, here designated: BM 000847081! [specimen on the right-hand side of sheet, image available at https://plants.jstor.org/stable/10.5555/al.ap.specimen.bm00084 7082, accessed 30 October 2018]; isolecto: K 000356720! [specimens at the bottom of the sheet, image available at http://apps.kew.org/herbcat/getImage.do?imageBarcode = K000356720, accessed 30 Oct. 2018]).

Palmer (2009, p. 120) indicated the specimen BM 000847081 as the 'holotype' of the name Amaranthus interruptus, with $\mathrm{K}$ 000356720 cited as an 'isotype', but these specimens were, in fact, syntypes (ICN Art. 9.6). The BM and K specimens are here designated as lectotype and isolectotype respectively, in accordance with ICN Art. 7.11. The BM specimen has been chosen as the lectotype because it is more complete, with good leaf and inflorescence material.

It should be noted that in this case, and in some cases discussed below (i.e. Amaranthus lineatus, A. macrocarpus var. pallidus, A. rhombeus, A. undulatus), the 'holotype' citations by Palmer (2009) cannot be automatically corrected to lectotype under ICN Art. 9.10, because such correction is possible only if the requirements of Art. 7.11 are met.

\section{Amaranthus lineatus R.Br., Prodr. 414 (1810)}

Type citation: '(T.) v. v.'. Type: 'North Coast', R.Brown Iter Australiense 3049 (lecto, here designated: BM 000884578! [image available at http://plants.jstor.org/specimen/bm000884578, accessed 30 October 2018]; isolecto: K 000356721 ! [specimens on the left-hand side of sheet, image available at http://apps.kew. org/herbcat/getImage.do?imageBarcode $=$ K000356721, accessed 30 October 2018]).

Palmer (2009, p. 120) indicated the specimen BM 000884578 as the 'holotype' of the name Amaranthus lineatus, with $\mathrm{K}$ 000356721 listed as an 'isotype'; however, these specimens were, in fact, syntypes (ICN Art. 9.6). The BM and K specimens are here designated as lectotype and isolectotype respectively, in accordance with ICN Art. 7.11 (see comment under $A$. interruptus). The BM specimen has been chosen as the lectotype because it comprises more complete material than does the $\mathrm{K}$ specimen. Amaranthus lineatus is now considered to be a taxonomic synonym of $A$. interruptus. 


\section{Amaranthus macrocarpus Benth., Fl. Austral. 5: 216 (1870), as 'Amarantus'}

Type: junction of the Murray and Darling, December 1853, $F$. Mueller s.n. (lecto: MEL 59717!; isolecto: K 000357413! [specimen on the left-hand side of sheet, image available at http://apps.kew.org/herbcat/getImage.do?imageBarcode = K000357413, accessed 30 October 2018], NSW 16811! [image available at http://plants.jstor.org/stable/history/10.5555/ al.ap.specimen.nsw16811, accessed 30 October 2018], fide J.Palmer, Nuytsia 19(1): 120 (2009)].

Amaranthus macrocarpus var. pallidus Benth., Fl. Austral. 5: 216 (1870); Amaranthus macrocarpus subsp. pallidus (Benth.) N.Bayón, Ann. Missouri Bot. Gard. 101(2): 338 (2015).

Type: Curriwillighi [Currawillinghi], s.d., F.C.Dalton s.n. (lecto, here designated: MEL 59713!; isolecto: K 000357414! [specimen on the right-hand side of sheet, image available at http://apps.kew.org/herbcat/getImage.do?imageBarcode = K000357414, accessed 30 October 2018]).

Amaranthus macrocarpus var. melanocarpus Thell. in P.F.A.Ascherson \& C.O.R.P.P.Graebner, Syn. Mitteleur. Fl. 5(1): 311 (1914), nom. inval. [ICN Art. 26.2; indicated as the type variety by Thellung].

Amaranthus macrocarpus var. rhodocarpus Aellen in G.Hegi, Ill. Fl. Mitt.-Eur. 2nd edn, 3(2): 500 (1959); Amaranth. Mitteleur. 500, 535 (1961), nom. inval. [ICN Art. 40.1; no type indicated].

Palmer (2009, p. 120) indicated the specimen MEL 59713 as the 'holotype' of the name Amaranthus macrocarpus var. pallidus, with K 000357414 as an 'isotype', but the specimens were, in fact, syntypes (ICN Art. 9.6). The MEL and K specimens are here designated as lectotype and isolectotype respectively, in accordance with ICN Art. 7.11 (see comment under A. interruptus). The MEL specimen has been chosen as the lectotype because it is a larger, more complete specimen than the fragmentary material at $\mathrm{K}$.

Earlier authors, including Palmer (2009), have recognised the following two infraspecific taxa in Amaranthus macrocarpus largely on the basis of fruit colour: A. macrocarpus Benth. var. macrocarpus (black fruit) and A. macrocarpus var. pallidus Benth. (pale or straw-coloured fruit). Additionally, an invalid designation 'Amaranthus macrocarpus var. rhodocarpus' was applied by Aellen (1959) to plants with red fruits. Although these entities are easily recognisable, they overlap in their distribution, and fruit colour is not routinely used as a character in defining taxa in Amaranthus. The infraspecific names are, thus, here synonymised under A. macrocarpus Benth. sens. lat.

5. Amaranthus mitchellii var. grandiflorus J.M.Black, Trans. \& Proc. Roy. Soc. South Australia 47: 368 (1923).

Type citation: 'Only known by one specimen in the Tate Herbarium, from Mount Parry, near Lake Torrens'. Type: Depot Creek, 10 June 1883, R.Tate s.n. (holo: AD 99436234! [top left-hand specimen]).

Black (1923,pp. 368, 369) cited a single specimen as the basis of Amaranthus mitchellii var. grandiflorus, giving the collection locality as 'Mount Parry, near Lake Torrens'. The herbarium sheet AD 99436234 contains material from two different taxa. The material mounted on the top left-hand side has an attached label reading 'Amaranthus Mitchellii Bth. var. grandiflora JMB' in Black's hand. The remaining material represents $A$. mitchellii Benth. var. mitchellii and bears an attached label 'No. 58 small plant on stones, water's edge, 20/6/84; only winter months' in the handwriting of James McLeod. Tate (1888) acknowledged receiving specimens collected by McLeod in 1884 near Innamincka; thus, the second specimen is from another gathering and cannot be considered original material of A. mitchellii var. grandiflorus. The only remaining locality information on the sheet is a small label reading 'Depot Creek, $10 / 6 / 83^{\prime}$ in the hand of Ralph Tate and a printed label taken from Tate (1883) reading 'Dry channels of Mount Parry and Depot Creeks'. It appears that Black, in citing the type locality for his new variety, used the generalised information from Tate (1883) rather than the specific label information (G. Bell, AD, pers. comm., 2008). This was corrected without comment in Palmer (2009) to 'Depot Creek, 10 June 1883, Herb. R. Tate s.n. (holo: AD 99436234)'.

Amaranthus mitchellii var. grandiflorus is currently considered to be a nomenclatural synonym of $A$. grandiflorus (J.M.Black) J.M.Black.

6. Amaranthus pallidiflorus var. viridiflorus Thell. in R.Probst, Mitt. Naturf. Ges. Solothurn 8(20): 60 (1928).

Type citation: 'Thellung, X. 1926'. Type: Western Australia: between the Ashburton \& Yule Rivers, s.d. [purchased 1898], E.Clement s.n. (neo, here designated: K 000357389! [image available at http://apps.kew.org/herbcat/getImage.do?image Barcode $=$ K000357389, accessed 29 October 2018]).

This variety was described by Thellung (in Probst 1928, p. 60) with the following short diagnosis:

Perianthium fructiferum tectura fiormiore (paleacea), tepalis ab nervum medianum (viridens remotum [ramulis anastomosantibus] medio viridibus ad $3 \frac{1}{2} \mathrm{~mm}$ longis et $1^{3} / 4$ m latis).

This was later corrected and slightly expanded by Thellung (in Probst 1932, p. 23) to the following:

Perianthium fructiferum tectura firmiore (paleacea), tepalis ob nervum medianum (viridem) dense ramosum (ramulis anastomosantibus) medio viridibus (nec hyalinus) ad $3 \frac{1}{2} \mathrm{~mm}$. longis et $1^{3} / 4 \mathrm{~mm}$. latis.

Thellung (in Probst 1928, p. 60) cited a single gathering ('Thellung, X. 1926'), with the notation 'Derend. K. K. 25, 26'. Probst (1928, p. 45) expanded this notation as 'Wollkompost der Kammgarnfabrik Derendingen', indicating that the plant had been observed as a weed arising from wool compost near the Derendingen woollen mills in 1925 and 1926.

According to Stafleu and Cowan (1986, p. 242), Thellung's herbarium collection is preserved mainly at $Z$, with other specimens being at BAS and MPU. Despite our enquiries and searches at these institutions and in online repositories, no original material has been traced and neotypification is, thus, desirable to fix the application of the name Amaranthus 
pallidiflorus var. viridiflorus. We select here the specimen $\mathrm{K}$ 000357389 as the neotype of the name, because the specimen matches the available descriptions by Thellung, in particular the broad bright green mid-nerves of the tepals.

Amaranthus pallidiflorus var. viridiflorus is currently considered to be a taxonomic synonym of $A$. clementii Domin. Our neotype specimen of $A$. pallidiflorus var. viridiflorus differs from the lectotype of $A$. clementii in having terminal inflorescences and longer, wider leaves. However, there is other material in Domin's herbarium (e.g. PR 526419) identified by him as $A$. clementii that is morphologically similar to the neotype of $A$. pallidiflorus var. viridiflorus. As outlined in Palmer (2009), these differences are considered to be merely variation within $A$. clementii rather than warranting the recognition of a distinct taxon.

7. Amaranthus quitensis Kunth in F.W.H.A. von Humboldt, A.J.A.Bonpland and K.S.Kunth, Nov. Gen. Sp. quarto edn, 2: 194 (1817).

Type citation: 'Crescit in ripa fluvii Guallabambae, alt. 1030 hex. (Regno Quitensi.)'. Type: [Ecuador], Quito, s. dat., A.Bonpland 3082 (lecto, here designated: P 00136030! [image available at https://science.mnhn.fr/institution/mnhn/collection/p/item/ p00136030, accessed 29 October 2018]).

Kunth (1817,p. 194) described Amaranthus quitensis on the basis of the collections made by Bonpland and Humboldt in South and Central America in the period 1799-1804. Costea et al. (2001,pp. 955,956) cited the type of A. quitensis as 'ECUADOR: ... 6, 1802, Humboldt \& Bonpland 3082 (HOLOTYPE: P?)'; however, we have not been able to trace a specimen exactly matching this citation. The specimen P 00136030 bears a label on the bottom left-hand side of the sheet, which reads: ' $N$ ': 3082 Amaranthus quitensis mihi $\mid$ Amaranthus viridis. aff. | at satis diversa spicis terminalibus elongatis $\mid$ Quito'. A second label on the bottom right-hand side of the sheet indicates that the plant is part of Bonpland's collection. This specimen is the only material of A. quitensis included in Bonpland's collection, but does not include the date ('June 1802') cited by Costea et al. (2001). Despite this, the original annotation 'mihi' (i.e. [belonging] to me) following the name indicates that $\mathrm{P} 00136030$ is part of the original material for A. quitensis. However, because we cannot exclude the possibility that some other specimens of the original material exist (see McNeill 2014), the specimen P 00136030 is here designated as the lectotype.

\section{Amaranthus rhombeus R.Br., Prodr. 414 (1810).}

Type citation: '(T.) v. v.'. Type: 'North Coast', R.Brown Iter Australiense 3050 (lecto, here designated: BM 000522509! [image available at https://plants.jstor.org/stable/viewer/10.5555/ al.ap.specimen.bm000522509]; isolecto: K 000356722! [specimen on the top right-hand side of sheet, image available at http://apps. kew.org/herbcat/getImage.do?imageBarcode $=\mathrm{K} 000356722$, accessed 29 October 2018]).

Palmer (2009, p. 123) indicated the specimen BM 000522509 as being the 'holotype' of the name Amaranthus rhombeus, with K 000356722 cited as an 'isotype'; however, the specimens were, in fact, syntypes (ICN Art. 9.6). The BM and K specimens are here designated as lectotype and isolectotype respectively, in accordance with ICN Art. 7.11 (see comment under A. interruptus). The BM specimen is chosen as the lectotype because it consists of more plentiful well-preserved material than does the $\mathrm{K}$ specimen.

\section{Amaranthus undulatus R.Br., Prodr. 414 (1810).}

Type citation: '(T.) v. v.' Type: Arnhem N Bay [Melville Bay, Northern Territory], R.Brown Iter Australiense 3047 (lecto, here designated: BM 000522508! [specimen on the right-hand side of sheet, image available at https://plants.jstor.org/stable/10.5555/ al.ap.specimen.bm000522508, accessed 29 October 2018]; isolecto: $\mathrm{K}$ 000357415! [image available at http://apps. kew.org/herbcat/getImage.do?imageBarcode $=\mathrm{K} 000357415$, accessed 29 October 2018]).

Palmer (2009, p. 123) indicated the specimen BM 000522508 as being the 'holotype' of the name Amaranthus undulatus, with K 000357415 as an 'isotype'; however, the specimens were, in fact, syntypes (ICN Art. 9.6). The BM and $\mathrm{K}$ specimens are here designated as the lectotype and isolectotype respectively, in accordance with ICN Art. 7.11 (see comment under A. interruptus). The BM specimen is chosen as the lectotype because it contains more complete material and because the label is annotated with the locality 'Arnhem N Bay', information that is missing from the $\mathrm{K}$ specimen.

\section{Conflicts of interest}

The authors declare that they have no conflicts of interest.

\section{Declaration of funding}

This research did not receive any specific funding.

\section{Acknowledgements}

Thanks are given to the directors and curators of all cited herbaria for their support during our visits, loans of specimens, and making available photographs of specimens. J. Palmer extends her thanks to Anna Monro for nomenclatural advice. We also thank the editors and reviewers for the useful suggestions given.

\section{References}

Aellen PL (1959) Amaranthus L. In 'Illustrierte Flora von Mitteleuropa'. (Ed. G. Hegi) Vol. 3(2), pp. 465-516. (Carl Hanser Verlag: München, Germany)

Bayón ND (2015) Revisión taxonómica de las especies monoicas de Amaranthus (Amaranthaceae): Amaranthus subg. Amaranthus y Amaranthus subg. Albersia. Annals of the Missouri Botanical Garden 101(2), 261-383. doi:10.3417/2010080

Black JM (1923) Additions to the Flora of South Australia No. 21. Transactions and Proceedings of the Royal Society of South Australia 47, 367-370.

Costea M, Sanders A, Waines G (2001) Preliminary results towards a revision of the Amaranthus hybridus complex (Amaranthaceae). Sida 19(4), 931-974.

Grenier M, Godron M (1846) 'Flore de France Prospectus.' (De Sainthe Agate Ainé: Besançon, France)

Hernández-Ledesma P, Berendsohn WG, Borsch T, von Mering S, Akhani H, Arias S, Castañeda-Noa I, Eggli U, Eriksson R, Flores-Olvera H, FuentesBazán S, Kadereit G, Klak C, Korotkova N, Nyffeler R, Ocampo G, 
Ochoterena H, Oxelman B, Rabeler RK, Sanchez A, Schlumpberger BO, Uotila P (2015) A taxonomic backbone for the global synthesis of species diversity in the angiosperm order Caryophyllales. Willdenowia 45(3), 281-383. doi:10.3372/wi.45.45301

Iamonico D (2010) Biology, life-strategy and invasiveness of Amaranthus retroflexus L. (Amaranthaceae) in central Italy: preliminary remarks. Botanica Serbica 34(2), 137-145.

Iamonico D (2015) Taxonomic revision of the genus Amaranthus (Amaranthaceae) in Italy. Phytotaxa 199, 1-84. doi:10.11646/phytotaxa. 199.1.1

Iamonico D (2016) Nomenclature survey of the genus Amaranthus (Amaranthaceae). 3. Names linked to the Italian flora. Plant Biosystems 150(3), 519-531. doi:10.1080/11263504.2014.987188

Iamonico D, El Mokni R (2018) Amaranthus tunetanus (Amaranthaceae), a new species from Tunisia and a diagnostic key to the North African taxa in subgen. Albersia. South African Journal of Botany 114, 78-83. doi:10.1016/j.sajb.2017.10.011

Kunth KS (1817) 'Voyage de Humboldt et Bonpland. Nova genera species plantarum', 4th edn, 2. (Librarie Grecque-Latine-Allemande: Paris, France)

McNeill J (2014) Holotype specimens and type citations: general issues. Taxon 63(5), 1112-1113. doi:10.12705/635.7

Mosyakin SL, Robertson KR (1996) New infrageneric taxa and combination in Amaranthus (Amaranthaceae). Annales Botanici Fennici 33(4), $275-281$

Mosyakin SL, Robertson KR (2003) Amaranthus L. In 'Flora of North America North of Mexico, 4 (Magnoliophyta: Caryophyllidae, part 1)'. (Ed. Flora of North America Editorial Committee) pp. 410-435. (Oxford University Press: New York, NY, USA)

Palmer J (2009) A conspectus of the genus Amaranthus L. (Amaranthaceae) in Australia. Nuytsia 19(1), 107-128.

Probst R (1928) Dritter Beitrag zur Adventivflora von Solothurn um Umgebung. Mitteilungen der Naturforschenden Gesellschaft in Solothurn 8(20), 41-82.

Probst R (1932) Vierter Beitrag zur Adventivflora von Solothurn um Umgebung. Mitteilungen der Naturforschenden Gesellschaft in Solothurn 9(21), 5-50.
Robertson KR (1981) The genera of Amaranthaceae in the southeastern United States. Journal of the Arnold Arboretum 62(3), 267-313. doi:10.5962/bhl.part.11251

Sauer JD (1950) The grain amaranths: a survey of their history and classification. Annals of the Missouri Botanical Garden 37(4), 561-632. doi: $10.2307 / 2394403$

Sauer JD (1955) Revision of the dioecious amaranths. Madrono 13(1), 5-46.

Sauer JD (1967) The grain amaranths and their relatives: a revised taxonomic and geographic survey. Annals of the Missouri Botanical Garden 54(2), 103-137. doi:10.2307/2394998

Stafleu FA, Cowan RS (1986) 'Taxonomic Literature, Vol. VI (Sti-Vuy)', 2nd edn. (Bohn, Scheltema \& Holkema: Utrecht, Netherlands; and Dr. W. Junk B.V., Publishers: The Hague, Netherlands)

Tate R (1883) List of some plants inhabiting the north-eastern part of the Lake Torrens Basin. Transactions, Proceedings and Reports of the Royal Society of South Australia 6, 100-106.

Tate R (1888) Plants of the Lake Eyre Basin. Transactions, Proceedings and Reports of the Royal Society of South Australia 11, 85-100.

Townsend CC (1985) Amaranthaceae. In 'Flora of tropical East Africa'. (Ed. RM Polhill) pp. 1-136. (A.A. Balkema: Rotterdam, Netherlands)

Turland NJ, Wiersema JH, Barrie FR, Greuter W, Hawksworth DL, Herendeen PS, Knapp S, Kusber W-H, Li D-Z, Marhold K, May TW, McNeill J, Monro AM, Prado J, Price MJ, Smith GF (Eds) (2018) 'International Code of Nomenclature for algae, fungi, and plants (Shenzhen Code)', adopted by the Nineteenth International Botanical Congress Shenzhen, China, July 2017. Regnum Vegetabile, vol. 159. (Koeltz Scientific Books: Königstein, Germany) doi:10.12705/ Code.2018.

Waselkov KE, Boleda AS, Olsen KM (2018) A phylogeny of the genus Amaranthus (Amaranthaceae) based on several low-copy nuclear loci and chloroplast regions. Systematic Botany 43(2), 439-458. doi:10.1600/036364418X697193

Handling editor: Daniel Murphy 